\title{
Military Spending and Unemployment: a panel Smooth Transition Regression Approach
}

\author{
Emmanuel Anoruo \\ College of Business \\ Coppin State University \\ USA \\ Uchenna Akpom \\ Department of Accounting \\ Finance and Economics \\ The University of West Alabama \\ Young D. Nwoye \\ Department of Accounting and Finance \\ Virginia State University
}

\begin{abstract}
This paper examines the empirical relationship between military spending and unemployment rates for a panel of 8 African countries using the panel smooth transition regression (PSTR) approach. This study adopts the PSTR model because of its ability to account for nonlinearity and/or heterogeneity and time instability that may be present in the panel. The PSTR model was estimated with a model with one transition function and one location parameter as dictated by the diagnostic tests. The diagnostic tests reveal that the relationship between unemployment rates and military spending is nonlinear. The results reveal that increases in military spending have significantly positive effect on unemployment rates in regime one; associated with low inflationary periods. However, in the second regime or high inflationary periods, increases in military spending deter unemployment. These results confirm that the relationship between unemployment rates and military spending is asymmetric and hence should be modeled accordingly. Policy wise, the results suggest that military spending should be increased during low inflation regime to mitigate the problem of unemployment. However, military spending is inconsequential during high inflation regime.
\end{abstract}

Keywords: Military spending; unemployment rates; PSTR; Threshold effect; Linearity test JEL Classifications: C51; E24; E32; E5; F5; O11

\section{Introduction}

The relationship between military spending and unemployment continues to attract the attention of military experts and policy makers given its implications for the macro economy. As espoused by Keynes, increases in defense spending are expected to engender aggregate demand and hence promote economic growth. However, the resources devoted to defense spending are no longer available for alternative uses. Unarguably, military spending may have adverse effect on production capacity if the foregone alternatives are consequential to economic growth, given that advanced technology is used in defense industry that requires intensive capital and qualified labor force. On the other, the investments made in defense industry may also serve the civilian sector; in which case, defense spending may have a positive effect on employment. Military spending may impact the labor market through a number of avenues. First, the construction of military infrastructure and the resulting productivity improvements from technological spillovers to the private sector will most likely increase the demand for labor. Second, the reallocation effect in the defense sector may lead to frictional unemployment which will in turn promote the supply of labor in the private sector. Third, the necessary taxes to finance the additional military spending will be borne by both the employers and workers. The payment of these taxes needed to finance military spending will affect both the demand and supply of labor. The existence of these alternative channels suggests that there is no clear-cut prediction of the sign of the effects of military spending on unemployment rates. 
This paper uses the PSTR model to investigate the impact of military spending on unemployment. This approach has a number of attractive features over the conventional frameworks such as the standard OLS.

First, the PSTR allows the regression coefficients to vary between countries and in time. This allows the researcher to examine the heterogeneous relationship between military spending and unemployment in time and across the countries. Second, the PSTR model allows for a smooth change in country-specific correlation depending on the threshold variables. This study uses inflation rates as the threshold variable in exploring the heterogeneity in time and across countries between military spending and unemployment rates for a panel of eight African countries. The results suggest that the relationship between military spending and unemployment rates is non-linear and this association can be affected by the inflation rates. Military spending is found to have a positive and statistically significant effect on unemployment for the low inflation regime (for inflation rate less than $11.54 \%$ ). However, the effect of military spending on unemployment is negative and statistically significant for the high inflation regime (for inflation above 11.54\%). The rest of the paper is organized as follows. Section 2 presents the literature review. Section 3 describes and summarizes the data. Section 4details the methodologies of the study. Section 5discusses the empirical results. Section 6offers the conclusions and policy implications of the study.

\section{Literature Review}

Tang, et al. (2009) examined the relationship between military expenditure and unemployment rates for a panel of 46 countries using panel Granger causality test. They found evidence of little causality running from unemployment to military expenditure. However, they find evidence of strong causality running from military expenditure to unemployment rates. Qiong and Junhua (2015) used the Autoregressive Distributed Lag model and data from 1991 to 2013 to test the relationship between military expenditure and unemployment in China. They found that military expenditure increases unemployment rate. In contrast, they found that increases in nonmilitary expenditure decreases unemployment rate in China. Korkmaz (2015) investigated the effects of military spending on economic growth and unemployment rate for 10 Mediterranean countries (Spain, BosniaHerzogevina, Croatia, Egypt, France, Greece, Israel, Italy, Turkey and Slovenia) for the period 2005 through 2012. He found military spending has adverse effects on economic growth and employment for the sample countries. Azam, et al. (2016) used the multivariate framework to explore the relationship between military expenditures and unemployment rate in a panel of selected SAARC countries including India, Nepal, Pakistan and Sri Lanka for the time period running from 1990 to 2013. The empirical results show that all the variables exhibit non-stationary behavior and have long-run relationships between them. They found that military expenditures engender employment rate in the SAARC region, given that the estimated coefficient of military expenditure has a negative relationship with unemployment rates. Sanso-Navarro and Cabello (2015) examined the causal relationship between military spending and unemployment rates in the EU15 countries using the panel bootstrap approach. They find little evidence in support of the notion that military spending does not cause unemployment. The little evidence they found was mainly for those countries that dedicatee higher percentage of their defense budget expenditures to personnel.

Paul (1996) investigated the pattern and the direction of causality between defense and nondefense spending and unemployment rate in 18 OECD countries for the time the period running from 1962 to 1988 using a threeequation near VAR (vector auto regression) model. He founds that defense spending has a favorable effect on unemployment rates for Germany and Australia. However, for Denmark, defense spending was found to have a detrimental effect on employment. He also found that nondefense spending and unemployment rates do not have causal influence on each other in the cases of Australia, Germany and Belgium. For UK, hefound defense spending has causal effect on unemployment rate. However, in the cases of Japan, The Netherlands, Italy, Spain, Austria, New Zealand, Sweden, Canada and the USA,he failed to find significant causal relationship between unemployment rate and either type of spending.

Dunne and Watson (2000) explored the long run relationship between military burden and manufacturing employment for South Africa. They found that military expenditure has adverse effect on manufacturing employment in South Africa, however Yildirim and Sezgin (2003) analyzed the effect of military spending on employment in Turkey and concluded that military spending increases employment because such expenditure may enhance aggregate demand in the economy. They however suggest that military expenditure devoted to hightechnology labor saving weapon systems may be detrimental to employment and hence promotes unemployment. In all, they conclude that military expenditure has an adverse negative effect on employment in Turkey. 
Huang and Kao (2005) using annual data from 1966 through 2002 explore the relationships between defense spending, employments in the private sector, GDP, and average monthly salary. They found that defense spending has a positive influence on employment in the long run. However, in the short run, they find that defense spending has a negative effect on employment. Malizard (2014) using the ARDL model examined the relationships between defense and nondefense spending and unemployment for the period running from 1975 to 2008. They found that both defense and nondefense spending have negative effect on unemployment. Payne and Ross (1992) investigate the effect of defense spending on real output, the unemployment rate, price level, and interest rate using an unrestricted vector autoregressive framework and quarterly data from 1960 through 1988. They found that there was no causal relationship in either direction between defense spending and unemployment rates.

It is obvious from the preceding literature review that African countries have not received adequate coverage regarding the relationship between military spending and unemployment. Most attention on such relationship has mainly focused on Asian and the OECD countries. I addition, most of the earlier studies on this topic applied either the VAR models or Ganger causality tests. These methodologies applied by the earlier studies do not account for the possible presence of nonlinearity in the relationship between military spending and unemployment. To fill gap, the present study uses the panel smooth transition regression (PSTR) developed by Fok, et al. (2005) and Gonzalez, et al. (2005) to explore the asymmetric relationship between military spending and unemployment for a panel of 8 African countries including - Botswana, Kenya, Lesotho, Mauritius, Malawi, Nigeria, Swaziland, and South Africa. This study adopted the PSTR model because it allows the military spending-unemployment coefficient to vary by country and with the time. The PSTR model allows individuals to move between groups and over time depending on changes in the threshold variable. The PSTR model also provides a parametric approach of the cross-country heterogeneity and of the time instability of the military spending-unemployment coefficients, since these parameters change smoothly as a function of a threshold variable, in this case the rate of inflation.

\section{Data and Descriptive Statistics}

The data for this study consist of annual observations on military spending, unemployment rates, interest rates, inflation rates and nonmilitary spending for a panel of 8 African countries namely-Botswana, Kenya, Lesotho, Mauritius, Malawi, Nigeria, Swaziland, and South Africa. The selection of the eight countries was based on the availability of consistent data for the study period. The sample period runs from 1988 through 2013. The data on military spending were retrieved from the website of the Stockholm International Peace Research Institute at http://www.sipri.org/databases. The data on unemployment rates, interest rates, inflation rates and nonmilitary spending were obtained from the World Development Indicators at http://databank.worldbank.orgpublished by the World Bank.The data on non-military spending were retrieved from the Pen World Tables 9.0 at www.ggdc.net/pwtprovided by Feenstra, et al. (2015).

Table 1: Descriptive Statistics

\begin{tabular}{|l|l|l|l|l|l|l|}
\hline Statistics & FDI & INF & INT & MS & NMS & UR \\
\hline Mean & 2.79 & 12.38 & 10.52 & 1.82 & 0.15 & 18.71 \\
\hline Median & 1.79 & 8.94 & 9.75 & 1.54 & 0.15 & 16.85 \\
\hline Maximum & 30.39 & 83.33 & 37.27 & 6.39 & 0.34 & 56.17 \\
\hline Minimum & -6.90 & -9.62 & 2.08 & 0.14 & 0.02 & 7.67 \\
\hline Std. Dev. & 4.42 & 11.75 & 5.82 & 1.25 & 0.06 & 8.58 \\
\hline Kurtosis & 23.07 & 14.63 & 7.75 & 3.14 & 3.62 & 8.36 \\
\hline Jarque-Bera & 4043.20 & $1501.28^{* * *}$ & $304.10^{* * *}$ & $23.22^{* * *}$ & $11.88^{* * *}$ & $399.60^{* * *}$ \\
\hline Probability & 0.00 & 0.00 & 0.00 & 0.00 & 0.00 & 0.00 \\
\hline Observations & 208 & 208 & 208 & 208 & 208 & 208 \\
\hline $\begin{array}{l}\text { No. of } \\
\text { Countries of }\end{array}$ & 8 & 8 & 8 & 8 & & 8 \\
\hline
\end{tabular}

indicates rejection of the null hypothesis of normality assumption at the $1 \%$ level of significance. FDI $=$ foreign direct investment (net inflows), INF $=$ inflation rates, INT $=$ interest rates, MS $=$ military spending percent of GDP, NMS = non-military spending percent of GDP, and UR= unemployment rates. 
Table 1 presents the descriptive statistics of foreign direct investment (FDI), military spending as a share of GDP (MS), unemployment rates (UR), interest rates (INT), inflation rates (INF), economic growth and nonmilitary spending as a share of GDP (NMS). The mean values are 2.79, 12.38, 10.52, 1.82, 0.15 and 18.71 percent, respectively for foreign direct investment, inflation rates, interest rates, military spending as a share of GDP, nonmilitary spending as a share of GDP, and unemployment rates. Based on the standard deviations, it can be inferred that inflation (11.75\%) fluctuated the most around the group mean. The least fluctuation was exhibited by nonmilitary spending $(0.06 \%)$. The Jarque-Bera statistics reveal that military spending, unemployment rates, interest rates, inflation rates, foreign direct investment and nonmilitary spending are not normally distributed. In all of the cases, the normality assumption is rejected at the $1 \%$ level of significance. The Kurtosis test statistics all exceed 3 indicating that the military spending, unemployment rates, interest rates, inflation rates and nonmilitary spending series are not normally distributed. Taken together, the results from both the Jarque-Bera and Kurtosis tests suggest that all of the series in the model are characterized by much higher distribution than the normal distribution. The minimum and maximum values reported in Table 1 reveal the degree of high variability in the various series in the study.

Table 2: Pairwise Correlation Coefficients

\begin{tabular}{|l|l|l|l|l|l|l|}
\hline & FDI & INF & INT & MS & NMS & UR \\
\hline FDI & 1.00 & & & & & \\
\hline INF & 0.04 & 1.00 & & & & \\
\hline INT & 0.04 & $0.58^{* * *}$ & 1.00 & & & \\
\hline MS & $0.23^{* * *}$ & $-0.12^{*}$ & $-0.15^{* *}$ & 1.00 & & \\
\hline NMS & 0.05 & $-0.34^{* * *}$ & $-0.38^{* * *}$ & $0.54^{* * *}$ & 1.00 & \\
\hline UR & -0.01 & $0.47^{* * *}$ & $0.82^{* * *}$ & $-0.29^{* * *}$ & $-0.43^{* * *}$ & 1.00 \\
\hline
\end{tabular}

and ${ }^{*}$ indicate level of significance at the $1 \%, 5 \%$ and $10 \%$, respectively. FDI $=$ foreign direct investment (net inflows), INF $=$ inflation rates, INT $=$ interest rates, MS $=$ military spending percent of GDP, NS = nonmilitary spending percent of GDP, and UR= unemployment rates.

Table 2 displays the correlation coefficients between foreign direct investment, inflation rates, interest rates, military spending as a share of GDP, nonmilitary spending as a share of GDP, and unemployment rates. The correction coefficients between unemployment rates and the explanatory variables range from -0.01 to 0.82 . The correlation coefficients between unemployment rates and foreign direct investment, inflation rates, interest rates, military and non-military spending are $-0.01,0.47,0.82,-0.29$, and -0.43 , respectively. The results indicate that the correlations between unemployment rates and all the explanatory variables, with exception of foreign direct investment are statistically significant at the 1percent level. For instance, the correlation between unemployment and military spending is negative and statistically significant at the 1 percent level $(r=-0.29, p=0.00)$.

\section{Econometric Methodology and Data Sources}

\section{Panel Unit Root Tests}

The tools for detecting the non-stationary of the data are the panel unit-root tests developed by Levin et al. (2002; LLC, hereafter), Breitung (2000), Maddala and Wu (1999; MW, hereafter), Hadri (2000), Choi (2001), and Imet al. (2003; IPS, hereafter); Fisher-Augmented Dickey-Fuller (Fisher-ADF); and Fisher-Phillips Perron (Fisher-PP). The tests are all based on estimation of the following Autoregressive/AR(1) process model:

$$
\mathrm{y}_{\mathrm{it}}=\rho_{\mathrm{i}} \mathrm{y}_{\mathrm{it}_{\mathrm{t}-1}}+\mathrm{zit}_{\mathrm{it}} \gamma_{\mathrm{i}}+\varepsilon_{\mathrm{it}}
$$

where $i=1,2,3, \ldots \ldots N$ denotes the number of countries in the panel for the study period $\mathrm{t}=1,2,3, \ldots \ldots \mathrm{T} ; y$ represents the variables of interest (in our case, military spending, interest rates, inflation rates, nonmilitary government spending, unemployment rates and economic growth). $\mathrm{zit}$ can denote both panel-specific means and panel specific means and a time trend, or nothing, depending on invoked options. If $\mathrm{z}_{i t}=1$, the term $\mathrm{z}_{i t} \gamma_{i}$ represents fixed effects. If $z^{\prime} i t=(1, t), z_{1}^{\prime} i \gamma_{i}$ represents panel-specific means and linear time trends. $\rho_{i}$ arethe autoregressive coefficients; and $\varepsilon_{i t}$ are the error terms. If $\left|\rho_{i}\right|=1$ then $y_{i}$ has a unit root, and if $\left|\rho_{i}\right|<1$, we could say $y_{i}$ is stationary. There are two assumptions about $\rho_{i}$ which classify panel unit root tests into two categories. First is the assumption that $\rho_{i}$ is constant across members of the panel $\left(\rho_{i}=\rho\right)$. 
LLC and Hadri tests are based on the first assumption. LLC test employs a null hypothesis of a unit root while Hadri test has a null hypothesis of no unit root. LLC test follows a basic ADF specification as follows:

$$
\Delta y_{i t}=\alpha y_{i t-1}+z^{\prime}{ }_{i t} \gamma_{i}+\sum_{j=1}^{p i} \theta_{i j} \Delta y_{i t-j}+\mu_{i t}
$$

where the assumption is that $\alpha=p-1$ and the lag order, $\rho_{\mathrm{i}}$ varies across cross-sections. $\Delta \mathrm{y}_{\mathrm{t}}=\mathrm{y}_{\mathrm{t}}-\mathrm{y}_{\mathrm{t}-1 .} \mu_{\mathrm{it}}$ are the error terms. The null and alternative hypotheses for the tests are: $\mathrm{H}_{0}: \alpha=0$ and $\mathrm{H}_{1}: \alpha<0$. Under the null hypothesis, there is a unit root, while under the alternative hypothesis, there is no unit root.

The second assumption is that $\rho_{\mathrm{i}}$ varies across panel members, which is underlying IPS, Fisher-ADF and Fisher-PP tests. To get a panel specific result, the tests combine individual unit root tests. The first step of IPS test is specifying a separate ADF regression for each panel member:

$$
\Delta y_{i t}=\alpha y_{i t-1}+z_{i t}^{\prime} \gamma_{i}+\sum_{j=1}^{\rho i} \theta_{i j} \Delta y_{i t-j}+\mu_{i t}
$$

With null hypothesis of $\mathrm{H}_{0}: \alpha_{\mathrm{i}}=0$ for all $i$, while the alternative hypothesis is $\mathrm{H}_{1}: \alpha_{\mathrm{i}}=0$ for $i=1,2,3, \ldots \ldots, \mathrm{N}$ and $\mathrm{H}_{1}: \alpha_{\mathrm{i}}<0$ for $i=\mathrm{N}+1, \mathrm{~N}+2, \mathrm{~N}+3, \ldots \ldots, \mathrm{N}$. After

$$
\mathrm{y}_{\mathrm{it}}=\alpha_{\mathrm{i}}+\beta \mathrm{x}_{\mathrm{it}}^{\prime}+\mu_{\mathrm{it}}, i=1,2, \ldots \ldots, \mathrm{N} ; \mathrm{t}=1,2, \ldots \ldots \ldots, \mathrm{T} \text {. }
$$

Where $\mathrm{y}_{\mathrm{it}}$ is a matrix $(1,1), \beta$ is a vector of slopes $(\mathrm{k}, 1)$ dimension, $\alpha_{\mathrm{i}}$ is an individual effect, $\mu_{\mathrm{it}}$ is an error term. It is assumed that $\mathrm{x}_{\mathrm{it}}(\mathrm{k}, 1)$ vector is an autoregressive process of the first difference:

$$
\mathrm{X}_{\mathrm{it}}=\alpha_{\mathrm{i}}+\mathrm{X}_{\mathrm{it}-1}+\varepsilon_{\mathrm{it}}
$$

\section{Panel Smooth Transition Regression (PSTR)}

This paper implements the PSTR model developed by Gonzàlezet al. (2005) and Foket al. (2005) to explore the nonlinear relationship between military spending and unemployment. The PSTR model has a number of attractive features. For instance, it accounts for nonlinear relationships between variables (in our case military spending and unemployment). It also allows regression coefficients to vary across individuals and over time. It divides the observations into regimes depending on the threshold reached by inflation which is adopted as the transition variable in this study.The regression coefficients between regimes are smooth andgradual. The PSTR models make it possible for the variables to transition from regime to the other in a smooth fashion rather than discrete. Based on the notations of the variables adopted by this study, the PSTR model is given by:

$U R_{i, t}=\alpha_{i}+\beta_{0} M S_{i, t} F\left(S_{i, t} ; \gamma ; c+\varnothing X_{i, t}+\mu_{i, t}\right.$

where UR represents unemployment rates, MS is military spending, $\alpha_{i}$ stands for country fixed effects, $F$ represents the transition function, $S_{\mathrm{i}, \mathrm{t}}$ stands for the transition variable (i.e. inflation rates, in our case), $\mathrm{X}_{\mathrm{i}, \mathrm{t}}$ denotes a vector of control variables that can include the transition variable, and $\mu_{\mathrm{i}, \mathrm{t}}$ represents the error term, assumed to be an independent and identically distributed. According to Gonzalez et al. (2005) the transition function $\mathrm{F}$ is normalized and bounded between 0 and 1 , and is given by:

$F\left(S_{i, t} ; \gamma ; c\right)=\left[1+\exp \left(-\gamma \prod_{j=1}^{m}\left(S_{i, t}-c_{j}\right)\right)\right]^{-1}$

Where $\gamma$ is the slope parameter and $c_{j}, j=1,2,3, \ldots, m$ are the threshold parameters $\left(c_{1} \leq c_{2} \leq \ldots \leq c_{m}\right)$. Thetwo most common cases in the literaturearem $=1$ (logistic) and $\mathrm{m}=2$ (logistic quadratic). For a logistic function, the dynamics is asymmetric and the two regimes are associated with small and large values of the transition variable in relation to the threshold. Under the logistic quadratic function, the dynamics are symmetric across the two regimes, however the intermediate regime follows a different dynamic compared to that in the extremes.

Inflation rates serve as the transition variable in this study.

The relationship between unemployment and its determinants is specified by a continuum of parameters depending on the transition variable (in our case, inflation rates). The parameters in the first regime are given by $\beta_{0}$ when $F()=$.0 , and by $\beta_{0}+\beta_{1}$ in the second regime when $F()=$.1 . Concentrating on the effect of military spending on unemployment, military spending has a different impact on the dynamics of the unemployment depending on the level of inflation. This effect varies between countries and time according to the value taken by the transition function as follows:

$\frac{d U R_{i, t}}{d M S_{i, t}}=\beta_{0}+\beta_{1} F\left(S_{i, t} ; \gamma ; c\right)$

In the case of $(\mathrm{r}+1)$ extreme regimes, the PSTR model can be generalized as follows: 
$U R_{i, t}=\alpha_{i}+\beta_{0} M S_{i, t}+\sum_{j=1}^{r} \beta_{j} M S_{i, t} * F\left(S_{i, t} ; \gamma_{j} c_{j}\right)+\emptyset^{\prime} X_{i, t}+\mu_{i, t}$

In this generalization, the effect of military spending on unemployment in functionof the transition variable is given by:

$\frac{d U R_{i, t}}{d M S_{i, t}}=\beta_{0}+\sum_{j=1}^{r} \beta_{j} * F\left(S_{i, t} ; \gamma_{j} ; c_{j}\right)$

The implementation of the PSTR model involves three methodological steps as suggested by Gonzalez, et al. (2005). The first step, known as the identification phase consists of (i) testing for linearity against alternative of a PSTR model; (ii) choosing the appropriate number of transition function(s). That is, determining whether the logistic $(\mathrm{m}=1)$ or the logistic quadratic $(\mathrm{m}=2)$ specification should be adopted. In step two -the estimation step, nonlinear least squares procedure is used to obtain the parameter estimates, after the data have been demeaned as suggested by Hansen (1999) and González, et al. (2005). In the third or the evaluation step, various misspecification tests are conducted to check the validity of the estimated PSTR model and determine the number of regimes. Details about the PTSR methodology can be found in Hansen (1999) and González et al. (2005).

\section{Empirical Results}

Table 3: Panel Unit Root Test Results

\begin{tabular}{|l|l|l|l|l|}
\hline Variable & LLC & IPS & ADF-Fisher & PP-Fisher \\
\hline FDI (Net Inflows) & $-2.56^{* * *}$ & $-2.61^{* * *}$ & $30.18^{* *}$ & $69.53^{* * *}$ \\
\hline INF & $-5.52^{* * *}$ & $-4.82^{* * *}$ & $60.47^{* * *}$ & $83.76^{* * *}$ \\
\hline INT & $-1.94^{* *}$ & $-3.90^{* * *}$ & $43.92^{* * *}$ & $23.75^{* *}$ \\
\hline MS & $-3.41^{* * *}$ & $-2.09^{* *}$ & $26.92^{* *}$ & $28.30^{* *}$ \\
\hline NMS & $-1.63^{* *}$ & $-2.47^{* * *}$ & $33.37^{* * *}$ & $59.36^{* * *}$ \\
\hline UR & $-1.50^{* *}$ & $-1.64^{* *}$ & $26.26^{* *}$ & $23.14^{*}$ \\
\hline
\end{tabular}

significance, respectively. FDI $=$ foreign direct investment $($ net inflows), INF $=$ inflation rates, INT $=$ interest rates, $\mathrm{MS}=$ military spending percent of GDP, NMS = non-military spending percent of GDP, and UR= unemployment rates.

Given that the individual dimension of the panel is less than the time dimension, it is important to check the variables for stationary. To this effect, this study uses the LLC, IPS, ADF-Fisher and PP-Fisher panel unit root tests to ascertain the order of integration for foreign direct investment, inflation rates, interest rates, military spending as a share of GDP, non-military spending as a share of GDP, and unemployment rates. The panel unit root test results are presented in Table 3. The results from the various panel unit root tests indicate that all of the variables are level stationary. For example, the test statistics from the LLC, IPS, ADF-Fisher and PP-Fisher for inflation rates are $-5.52,-4.82,60.47$ and 83.76 , respectively. These panel unit root test statistics for inflation rates are statistically significant at the 1 percent level.

\section{Table 4: Linearity Test Results}

\begin{tabular}{|l|l|l|l|l|}
\hline & $(1,1)$ & \multicolumn{3}{l|}{$(1,2)$} \\
\hline & Statistic & $P$-value & Statistic & $P$-value \\
\hline Wald Tests $\left(\mathrm{LM}_{\mathrm{w}}\right)$ & $15.07^{* * * *}$ & 0.01 & $31.63^{* * * *}$ & 0.00 \\
\hline Fisher Tests $\left(\mathrm{LM}_{\mathrm{F}}\right)$ & $3.83^{* * *}$ & 0.01 & $4.31^{* * *}$ & 0.00 \\
\hline Likelihood Ratio Tests $\left(\mathrm{LR}_{\mathrm{T}}\right)$ & $15.64^{* * * *}$ & 0.00 & $34.32^{* * * *}$ & 0.00 \\
\hline
\end{tabular}

${ }^{* * *}$ and ${ }^{* *}$ indicate rejection of the null hypothesis of linearity at the $1 \%$ and $5 \%$ significance level, respectively. $r$ is the number of transition functions, $m$ is the location parameter.

Having established that the variables have zero order of integration, the study next examines whether there is a non-linear relationship among inflation rates, interest rates, military spending, non-military spending and unemployment rates. Table 4 displays the linearity test results. The results from the Wald, Fisher and Likelihood ratio tests suggest that the null hypothesis of linearity should be rejected at the 1 percent level of significance. These results suggest that the relationships between unemployment rates, inflation rates, interest rates, military spending, nonmilitary spending are nonlinear and should be modeled accordingly. 
The next step of the study is to determine the appropriate number of regimes/transition functions. Table 5displays the results from the Wald, Fisher and Likelihood ratio tests for no remaining non-linearity in the model. The null hypothesis is that there is a PSTR model with only one threshold variable; while the alternative hypothesis is that there is a PSTR model with at least 2 threshold levels. The results fail to reject the null hypothesis that there is a PSTR model with only threshold variable (i.e. $r=1$ ). These results imply that there is only one threshold level of inflation which divides the sample into two regimes (low and high inflation regimes).

Table 5: Test of No Remaining Nonlinearity/Determination of the Number of Regimes

\begin{tabular}{|l|l|l|}
\hline $\mathrm{H}_{0}$ : PSTR with $\mathrm{r}=1$ against $\mathrm{H}_{\mathrm{1}}$ : PSTR with at least $\mathrm{r}=2$ & \multicolumn{2}{l|}{$(\mathrm{r}=1, \mathrm{~m}=1)$} \\
\hline & Statistic & $P$-value \\
\hline Wald Tests $(\mathrm{LM})$ & 5.19 & 0.27 \\
\hline Fisher Tests $\left(\mathrm{LM}_{\mathrm{F}}\right)$ & 1.20 & 0.31 \\
\hline Likelihood Ratio Tests $\left(\mathrm{LR}_{\mathrm{T}}\right)$ & 5.25 & 0.26 \\
\hline
\end{tabular}

$r$ is the number of transition functions, $m$ is the location parameter. The null hypothesis of these tests is a single threshold (two regimes) while the alternative hypothesis is of at least two thresholds (at least three regimes).

At this juncture, the study uses AIC, Schwarz Criterion (BIC) and residual sum of squares tests to determine the optimal number of location parameters. Table 6 displays the results from the RSS, AIC and BIC test results. The results from these tests suggest $\mathrm{m}=1$ should be selected as the appropriate number of location parameter. The test results from the RSS (1644.39), AIC (2.22) and Schwarz Criterion (2.38) are smaller for when $\mathrm{m}=1$ than when $\mathrm{m}=2$. These results indicate that there should be one location parameter in modeling the asymmetric relationship between interest rate and military expenditures. Based on the results from Tables 5 and 6 , it be surmised that the appropriate PSTR model for modeling the relationship between unemployment rates and military spending should be based on the specification $\mathrm{m}=1$ and $\mathrm{r}=1$.

Table 6: Determination of the Number of Location Parameters

\begin{tabular}{|l|l|l|}
\hline Threshold Number & $\mathrm{m}=1$ & $\mathrm{~m}=2$ \\
\hline Residual Sum of Squares (RSS) & 1644.39 & 1664.26 \\
\hline AIC & 2.22 & 2.25 \\
\hline Schwarz Criterion (BIC) & 2.38 & 2.42 \\
\hline
\end{tabular}

Note: $\mathrm{m}$ is the location parameter.

The results from the PSTR are presented in Table 7. It is important to point out that the threshold variable is country-specific and time-varying. The regression coefficients under the PSTR are allowed to change for each of the countries in the panel along with the time. Given the fact that different countries in the panel may not take immediate and identical actions at the same time due to the presence of heterogeneity. Consequently, it is difficult to directly interpret the values of these regression coefficients. To this end, it is preferable to interpret the sign of the regression coefficients from the PSTR, which indicate increases or decreases in the independent variables on the dependent variable depending on the value of the threshold variable. Given that the estimated parameters cannot be directly interpreted, it is therefore important or/preferred to interpret the signs of the regression coefficients.

Table 7: PSTR Estimation (Dependent Variable: Unemployment Rates)

\begin{tabular}{|l|l|l|l|l|}
\hline & First Regime & \multicolumn{2}{l|}{ Second Regime } \\
\hline & Coefficient & $t$-value & Coefficient & $t$-value \\
\hline FDI & $-0.12^{* * *}$ & -2.21 & $0.62^{* * *}$ & 3.34 \\
\hline INT & $1.09^{* * *}$ & 18.52 & $-0.21^{* *}$ & -2.79 \\
\hline MS & $-1.29^{* * *}$ & -3.62 & 0.11 & 0.26 \\
\hline NMS & $-29.92^{* * *}$ & -4.51 & -5.64 & -0.78 \\
\hline Slope Parameter $(\gamma)$ & $1.47 \mathrm{e}^{+004}$ & & & \\
\hline Location Parameter $(c)$ & $11.54 \%$ & & & \\
\hline
\end{tabular}

${ }^{* * *}$ and ${ }^{* *}$ indicate level of significance at the $1 \%$ and 5\%, respectively. FDI $=$ foreign direct investment (net inflows), INT = interest rates, MS = military spending percent of GDP and NMS = non-military spending percent of GDP. 
The results reported in Table 7 are based estimates from the PSTR model with one transition function and one location parameter (i.e. $\mathrm{r}=1, \mathrm{~m}=1$ ). From Table 7 , it can be seen that the slope parameter $(\gamma)$ is $1.47 \mathrm{e}^{+004}$. This suggests that a smooth and continuous transition function exists between the two regimes. The threshold value/location parameter of the model is $11.54 \%$, as reported in column 1, row 8 of Table 7 . The threshold value/location parameter reveals the point where the activity switches from one regime to another. The first regime corresponds to the values of the transition variable that is below the threshold parameter $(11.54 \%$, in our case). The second regime, on the other hand, corresponds to the values of the transition variable that is above the threshold parameter $(11.54 \%)$. The results indicate that increases in military spending have significantly negative effect on unemployment rates in the first regime when inflation rates are below $11.54 \%$. This implies that during periods of low inflation regime, military spending tends to deter unemployment. In other words, increases in military spending promote civilian employment during high inflationary periods for the panel member countries under study. However, increases in military spending have insignificant impact on unemployment rates in the second regime when inflation rates are above $11.54 \%$.

Turning next to the effects of the control variables on employment rates, it can be seen from Table 7 that that increases in foreign direct investment have significantly negative impact on unemployment rates in the low inflation regime. However, in the high inflation regime, increases in foreign direct investment have significantly positive effect on unemployment rates. The results further reveal that increases in interest rates have significantly positive impact on unemployment rates in the first regime. However, in the second regime, increases in interest rates have insignificant effects on unemployment rates. The results also show that increases in nonmilitary have significantly negative influence on unemployment rates in the first regime. This finding implies that during periods of low inflation, nonmilitary spending tends to retard unemployment. Simply put, increases in nonmilitary spending promote civilian employment during low inflationary periods. However, in the second regime, increases in nonmilitary spending have insignificant effects on unemployment rates.

\section{Conclusion and Policy Implications}

This paper has used the panel smooth transition regression (PSTR)approach to examine the relationship between military spending and unemployment for group of 8 African countries, using inflation rates as the threshold variable, for the period running from 1988 through 2013.Thesample countries are Botswana, Kenya, Lesotho, Mauritius, Malawi, Nigeria, Swaziland, and South Africa. Inflation rate was used as the transition variable to expand on the heterogeneity in time and country between military spending and unemployment. The results from the panel unit root tests of LLC, IPS, ADF-Fisher and PP-Fisher suggest that all the variables in the study have one order of integration. The results reveal that the relationship between military spending and unemployment is nonlinear. The existence of nonlinearity implies that threshold effect can be identified in the relationship between military spending and unemployment.

Our results of this study reveal the consecutive change in inflation threshold level which enables the effect military spending on unemployment to undertake smooth and gradual transition from a high to a low inflation regime. Military spending has a positive and statistically significant effect on unemployment for the low inflation regime. However, the effect of military spending on unemployment is negative and statistically significant for the high inflation regime.

The effect of interest rate on unemployment is positive and statistically significant in low inflation regime and negative and statistically insignificant in the high regime. Non-military pending has a negative and statistically significant effect on unemployment in the low inflation regime and positive and statistically significant in the high regime.

\section{Acknowledgments}

The authors are grateful to Professor Fouquau and Professor Hurlin for kindly making available the MATLAB computer codes used in this paper. All remaining errors are ours. 


\section{References}

Azam, Muhammad, Faisal Khan, Khalid Zaman, and Amran Md. Rasli (2016) MilitaryExpenditures and Unemployment Nexus for Selected South Asian Countries, Social Indicators Research,127, 1103-1117.

Colletaz, G. and Hurlin C. (2006). Threshold Effects in the Public Capital Productivity: An International Panel Smooth Transition Approach, Document de Recherche du Laboratoireconomied'Orleans.

Dunne, P., Watson, D. (2000), Military Expenditure and Employment in South Africa, Defense AndPeace Economics, 11(4), 587-596.

Fok, D., Dijk, D.V. and Franses, P.H., 2005. A Multi-Level Panel STAR Model for US Manufacturing Sectors. Journal of Applied Econometrics, 20, 811-827.

Fouquau J., Hurlin C. andRabaud I. (2008). The Feldstein-Horioka Puzzle: A Panel Smooth Transition Regression Approach, Economic Modelling, vol. 25(2), pp. 284-299

Feenstra, Robert C., Robert Inklaar and Marcel P. Timmer (2015), "The Next Generation of the Penn World Table" American Economic Review, 105(10), 3150-3182, available for download at www.ggdc.net/pwt

González, A., Teräsvirta, T., van Dijk, D., 2005. Panel smooth transition regression models. SEE/EFI Working Paper Series in Economics and Finance, No. 604.

Hansen, B. (1999) Threshold effects in non-dynamic panels: Estimation, testing, and inference, Journal of Econometrics, 93, pp. 345-368.

Huang, J-T., Kao, A-P. (2005), Does Defence Spending Matter to Employment in Taiwan?, Defence and Peace Economics, 16(2), 101-115.

Im, K.S., Pesaran, M.H. and Shin, Y. (2003) Testing for unit roots in heterogeneous panels.Journal of Econometrics.115,53-74.

Jude, Eggoh (2010) Financial Development and Growth: A Panel Smooth Regression Approach.Journal of Economic Development, 35(1), 15-33.

Korkmaz, Suna (2015) The Effect of Military Spending on Economic Growth and Unemploymentin Mediterranean Countries, International Journal of Economics and Financial Issues, 5(1), 273-280.

Levin, A., Lin, C.-F. and Chu, C.-S.J. (2002) Unit root tests in panel data: asymptotic and finite- sample properties. Journal of Econometrics 108(1) 1-24.

Malizard, J. (2014), Defense Spending and Unemployment in France, Defense and PeaceEconomics, 25(6), 635642.

Paul, Satya (1996) Defense spending and unemployment rates: An empirical analysis for theOECD, Journal of Economic Studies, 23 (2): 44-54.

Payne, J.E. and Ross, K. (1992) Defense Spending and Macroeconomy, Defense Economics 3(2) 161-168.

Qiong, Li and Hu Junhua (2015) Military Expenditure and Unemployment in China, 30, 498-504.

Sanso-Navarro, Marcos and Vera-Cabello, María (2015). The Causal Relationship betweenMilitarySpending and Unemployment in the EU15 (January 15, 2015). Available at SSRN:https://ssrn.com/a bstract=25501 36 or http://dx.doi.org/10.2139/ssrn.2550136.

Tang, Jenn- Hong, Cheng- Chung Lai and Eric S. Lin (2009) Military Expenditure and

Unemployment Rates: Granger Causality Tests using Global Panel Data, Defense and Peace Economics, 20:4, 253-267.

Yildirim, J., Sezgin, S. (2003), Military Expenditure and Employment in Turkey, Defense and

Peace Economics, 14(2), 129-139. 